the cardiovascular hazards that are associated with acute anxiety in this situation.

We would like to thank Dr. M. Carruthers and Dr. R. Robinson for their help and encouragement. Our acknowledgements are also due to Mr. D. Williams and Dr. E. J. Hindle, of the department of clinical chemistry, Queen Elizabeth Hospital, and Mr. E. Legg, of the department of clinical chemistry, Dudley Road Hospital, for their technical help. This investigation was supported by grants from the Rowbotham Bequest Fund and Roche Products Ltd.

Requests for reprints should be addressed to Dr. H. D. Edmondson. The Dental School, St. Mary's Row, Birmingham B4 6NN.

\section{References}

Breggin, P. R. (1964). Fournal of Nervous and Mental Disease, 139, 558. Carruthers, M. (1972). Automation in Analytical Chemistry, ed. L. T. Skeggs. In press.

Carruthers, M., Taggart, P., Conway, N., Bates, D., and Sommerville, W. (1970). Lancet, 2, 62.

Cramp, D. G., and Robertson, G. (1968). Analytical Biochemistry, 25, 246. Healy, T. E. J., Robinson, J. S., and Vickers, M. D. (1970). British Medical fournal, 3,10.

Lautch, H. (1971). British fournal of Psychiatry, 119, 151.

McCullough, H. J. (1968). Fournal of Clinical Pathology, 21, 759.

McCullough, H. J. (1968), Fournal of Clinical Pathoh,

Pisano, J. J. (1960). Clinica Chimica Acta, 5, 406.

Robinson, R., Ratcliffe, J., and Smith, P. (1959). fournal of Clinical Patho$\log y, 12,541$.

Taggart, P., and Carruthers, M. (1971). Lancet, 1, 363.

\title{
Plasma Levels and Therapeutic Effect of 25-Hydroxycholecalciferol in Epileptic Patients taking Anticonvulsant Drugs
}

\author{
T. C. B. STAMP, J. M. ROUND, \\ D. J. F. ROWE, \\ J. G. HADDAD
}

British Medical fournal, 1972, 4, 9-12

\section{Summary}

Plasma levels of 25-hydroxycholecalciferol (25-HCC) were measured by a specific competitive protein-binding assay. Mean levels in both normal London adults and adolescent schoolchildren were $16 \mathrm{ng} / \mathrm{ml}$ and the mean level in a group of epileptic patients on high-dosage anticonvulsant therapy was $5 \mathrm{ng} / \mathrm{ml}$, (difference from normals $P<0.001$ ). Two further epileptic patients, with well-marked anticonvulsant osteomalacia, were treated with small doses of 25-HCC during full metabolic balance studies; rapid healing followed administration of 25-HCC by mouth in doses of 10-45 $\mu \mathrm{g}$ daily, which is well below the effective dose range of calciferol in this condition. These findings provided further evidence that anticonvulsant osteomalacia results from hepatic enzyme induction which, by increasing the metabolism of cholecalciferol to inactive compounds, lowers 25-HCC levels in patients whose dietary vitamin $D$ intake and exposure to sunlight are otherwise adequate. Results also indicated that under certain circumstances 25-HCC may have considerably stronger antirachitic potency in man than has hitherto been recognized.

\section{Introduction}

The occurrence of rickets and osteomalacia among epileptic patients taking long-term anticonvulsant drugs in high dosage was first reported by Kruse (1968). A subsequent report confirming this observation postulated that hepatic enzyme induction was responsible for enhancing the hydroxylation of cholecalciferol (vitamin $\mathrm{D}_{3}$ ) to inactive metabolites and thereby greatly increasing the patient's requirement for the vitamin (Dent, Richens, Rowe, and Stamp, 1970).

25-Hydroxycholecalciferol (25-HCC) is the major circulating

Metabolic Ward, University College Hospital, London W.C.1

T. C. B. STAMP, M.B., M.R.C.P., Wellcome Research Fellow

J. M. ROUND, B.SC., Biochemist

D. J. F. ROWE, B.SC., Biochemist

Department of Medicine, Washington University School of Medicine Jewish Hospital of St. Louis, St. Louis, Missouri 63110, U.S.A.

J. G. HADDAD, M.D., Assistant Professor of Medicine metabolite of cholecalciferol. It is produced from cholecalciferol only by liver (DeLuca, 1969) and is the immediate precursor of 1,25-dihydroxycholecalciferol, which is now regarded as the biologically active, hormonal form of the vitamin (Kodicek, Lawson, and Wilson, 1970; Holick, Schnoes, and DeLuca, 1971; Lawson, Fraser, Kodicek, Morris, and Williams, 1971). It was therefore important to test whether circulating levels of 25-HCC were abnormally low in subjects receiving high doses of anticonvulsant drugs, as would be expected on the above premise, and also to test the possibility that administration of 25-HCC itself might therefore be appreciably superior to calciferol in the treatment of anticonvulsant osteomalacia.

\section{Subjects and Methods}

Adult controls consisted of healthy academic and laboratory staff who were resident in London, and adolescent controls (in whom other plasma determinations were also performed) were boys, evenly divided between the ages of 11-17, in secondary schools under the Inner London Education Authority. The subjects or their parents were informed volunteers in the project. Epileptic subjects who were otherwise healthy were sampled from among the population of a Buckinghamshire epileptic colony whose diet contained adequate amounts of vitamin $D$ ( $>70$ IU daily) and who spent several hours a week out of doors. All were taking at least two of the major anticonvulsant drugs, each in high dosage. Two further epileptic patients whose case histories are recorded below had clinical evidence of osteomalacia, which was later confirmed on both biochemical and histological grounds.

25-HCC was measured by the assay of Haddad and Chyu (1971). Briefly, ether extracts of plasma were chromatographed on silicic acid columns to separate 25-HCC from cholecalciferol and from more polar metabolites. Aliquots of the 25-HCC fractions compete : vith ${ }^{3} \mathrm{H}(26,27)-25-\mathrm{HCC}$ for binding to the $100,000-g$ supernatant prepared from rachitic rat kidney homogenates. Dextran-coated charcoal absorbs unbound tracer sterol, and the supernatant counts were compared with those from a standard curve prepared from ethanol solutions of crystalline 25-HCC (courtesy of Dr. John Babcock, Upjohn Pharmaceuticals Kalamazoo, Michigan).

Metabolic balance studies were performed according to standard principles (Reifenstein, Albright, and Wells, 1945) improved by the use of cuprous thiocyanate as an internal marker (Dick, 1969). 


\section{Results}

\section{PLASMA LEVELS OF 25-HCC}

Individual values are shown in Fig. 1 for 19 normal adults, 12 normal adolescents, and 11 epileptic adults on long-term was $15 \cdot 8 \pm 1.4$ (S.E. of mean) $\mathrm{ng} / \mathrm{ml}$, in adolescents $16.3 \pm 1 \cdot 6$, and in epileptic patients $4.8 \pm 0 \cdot 8$. Mean levels in normal adults and adolescents were thus very similar, while $25-\mathrm{HCC}$ levels in epileptic patients were very much lower than either (difference from normal adults, $t=5.55, \mathrm{P}<0.001$ ).

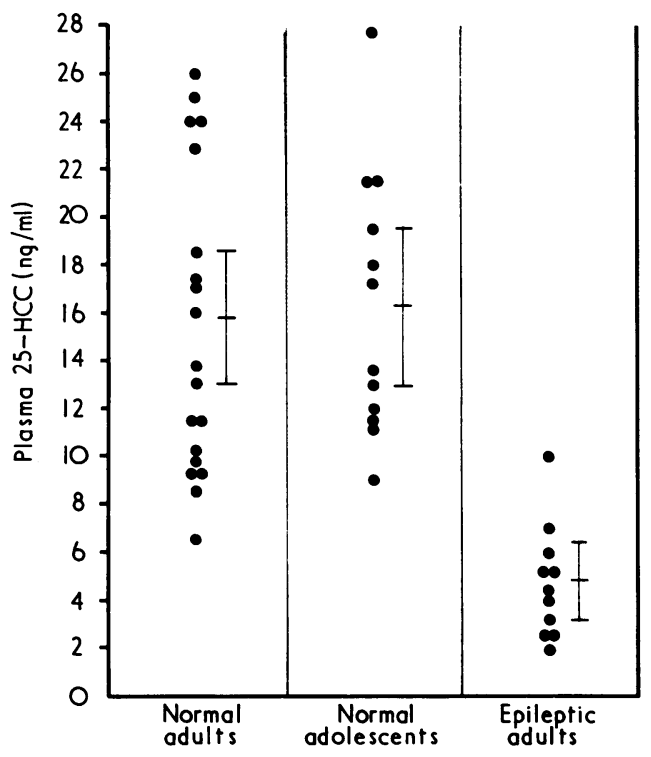

FIG. 1-Plasma levels of 25-HCC in 19 normal adults, 12 normal boys aged 11-17, and 11 adults with epilepsy on long-term anticonvulsant therapy. Bars indicate mean \pm 2 S.E. of mean.

\section{TREATMENT OF ANTICONVULSANT OSTEOMALACIA}

\section{Case 1}

A 47-year-old woman was admitted to the metabolic ward in November 1971 with a history of idiopathic major epilepsy since the age of 5 . For eight years she had been resident in an epileptic colony, and for most of this time had been taking primidone $1,250 \mathrm{mg}$ daily, phenytoin $300 \mathrm{mg}$. daily, and ethosuximide 150 $\mathrm{mg}$ daily. She had suffered two fractures of her right tibia in 1963. On examination her affect was dull, she had severe acne rosacea, and skeletal measurements suggested some $4 \mathrm{~cm}$ of trunk shortening. A summary of initial investigations is shown in the Table. Radiography showed generalized skeletal rarefaction with biconcave lumbar vertebrae and subperiosteal and tuft erosions in the phalanges. Except for a mild systemic acidosis (bicarbonate $20 \mathrm{mmol} / 1$., chlorine $107 \mathrm{mEq} / \mathrm{l}$.) all other routine investigations were normal. Metabolic balance studies and results of treatment are shown in Fig. 2. Control periods showed an osteomalacic pattern with high faecal and low urinary calcium. Treatment with oral calciferol $45 \mu \mathrm{g}(1,800 \mathrm{IU})$ daily produced no change in her balance or plasma chemistry.

After further control periods the patient was then treated with 25-HCC $45 \mu \mathrm{g}$ daily by mouth and rapid healing followed. Her calcium balance quickly became positive to the extent of $500 \mathrm{mg}$ daily and plasma chemistry returned to normal. Her improvement was sustained when whole-body ultraviolet irradiation to the limits of tolerance was substituted for 25-HCC, and her acne also high-dosage anticonvulsant therapy. The mean value in adults

improved. After an early "alkaline phosphatase flare" to 20 K.A.U. levels fell gradually to 14 K.A.U. by the time she was discharged, taking calciferol $0.25 \mathrm{mg}$ daily.
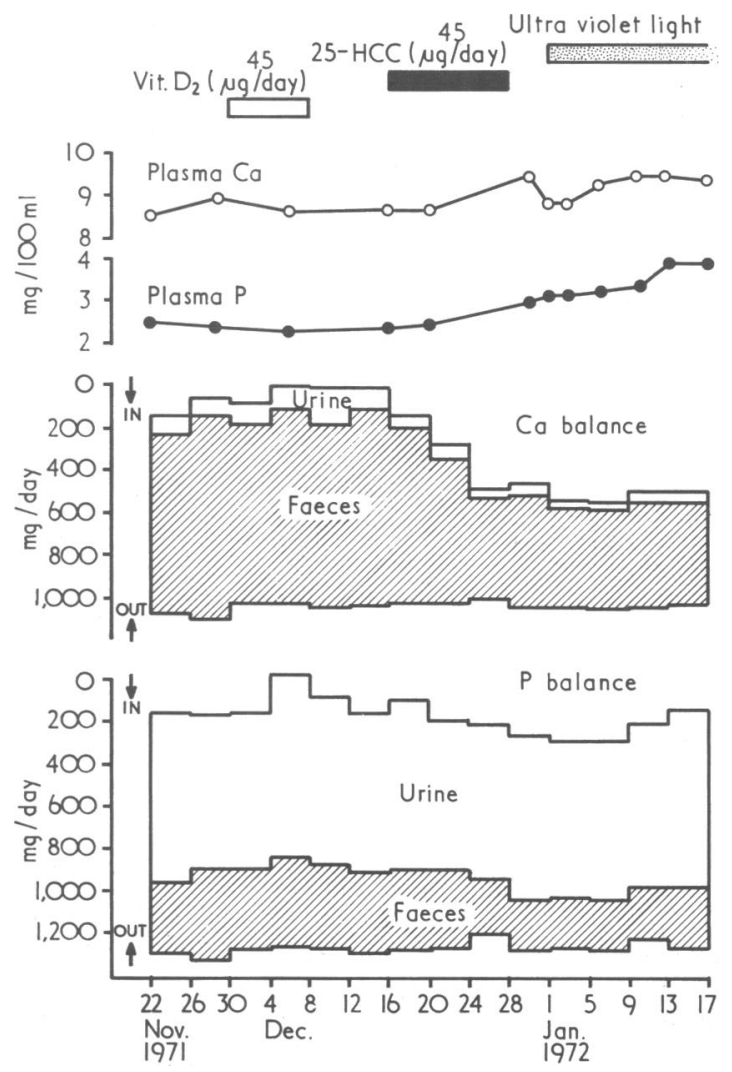

FIG. 2-Metabolic balance data in Case 1. Note pronounced improvement in balance and plasma chemistry when 25-HCC was substituted for vitamin D, and continued healing when ultraviolet irradiation to the limits of tolerance was substituted for 25 -HCC.

\section{Case 2}

A 57-year-old man was admitted to the metabolic ward in April 1972 with a history of idiopathic major and minor epilepsy since the age of 16. He had been resident in an epileptic colony for 20 years, and for five years his treatment had consisted of primidone $750 \mathrm{mg}$ daily and phenytoin $300 \mathrm{mg}$ daily. For one year he had also been taking a multivitamin preparation providing 500 IU calciferol $(12.5 \mu \mathrm{g})$ daily. He had suffered a profusion of fractures including those of metacarpals, clavicle, nose, skull, and mandible. He had undergone surgical correction of bilateral Dupuytren's contracture. He shaved irregularly. Hypopituitarism had been diagnosed elsewhere in 1969, and in addition to his anticonvulsant therapy and vitamin D he was also receiving cortisone acetate $25 \mathrm{mg}$ daily and thyroxine sodium $0.1 \mathrm{mg}$ daily.

On examination he was pale, talkative, and had a schizoid personality. Secondary hair was scanty, testes were small, and skeletal measurements were: crown to pubis $72 \mathrm{~cm}$, pubis to sole $85 \mathrm{~cm}$, and span $167 \mathrm{~cm}$. Initial investigations are summarized in the Table. Radiography showed mild skeletal rarefaction, a partlyhealed right clavicular fracture, and mild biconcavity of the lumbar vertebrae. He showed a normal response of ${ }^{131}$ I uptake to thyroid stimulating hormone and a normal plasma cortisol response to tetracosactrin (Synacthen). Urinary steroid excretion was abnormally low and showed a subnormal response to metyrapone. Cortisone was stopped soon after admission and plasma cortisol levels remained well within the normal range. Results of all other

Summary of Initial Investigations in Two Patients with Anticonvulsant Osteomalacia

\begin{tabular}{|c|c|c|c|c|c|c|}
\hline \multirow[b]{2}{*}{$\begin{array}{l}\text { Case } \\
\text { No. }\end{array}$} & \multicolumn{3}{|c|}{ Plasma } & \multicolumn{2}{|c|}{ Urine } & \multirow{2}{*}{ Bone Histology } \\
\hline & $\underset{(\mathrm{mg} / 100 \mathrm{ml})}{\text { Calcium }}$ & $\begin{array}{l}\text { Phosphorus } \\
(\mathrm{mg} / 100 \mathrm{ml})\end{array}$ & $\begin{array}{l}\text { Alkaline Phosphatase (K.A.U.) } \\
\text { Acrylamide Gel Electrophoresis }\end{array}$ & $\underset{(\mathrm{mg} / 24 \mathrm{hr})}{\text { Calcium }}$ & $\begin{array}{l}\text { Aminoacid } \\
\text { Chromatogram }\end{array}$ & \\
\hline $\begin{array}{ll}1 \\
2 & \cdots\end{array}$ & $\begin{array}{l}8 \cdot 4 \\
8 \cdot 2\end{array}$ & $\begin{array}{l}2 \cdot 3 \\
2 \cdot 7\end{array}$ & $\begin{array}{l}80 \% \text { bone } \\
90 \% \text { bone }\end{array}$ & $\begin{array}{l}91 \\
22\end{array}$ & $\begin{array}{l}\text { Increased glycine } \\
\text { Normal }\end{array}$ & $\begin{array}{l}\text { Osteomalacia and hyperparathyroidism } \\
\text { Osteomalacia and hyperparathyroidism }\end{array}$ \\
\hline
\end{tabular}


routine investigations were normal. Metabolic balance studies and results of treatment are shown in Fig. 3. Control balance periods showed an osteomalacic pattern with high faecal and low urinary calcium despite continuing treatment with calciferol $12.5 \mu \mathrm{g}$ daily. On substituting 25-HCC $10 \mu \mathrm{g}$ daily by mouth his calcium and phosphorus balance began to improve almost immediately and his plasma calcium and phosphorus levels rose. By the time stepwise increments in 25-HCC had reached a dose of $40 \mu \mathrm{g}$ daily his calcium balance had become positive to the extent of $400 \mathrm{mg}$ daily. Plasma alkaline phosphatase had declined slowly to 13 K.A.U.
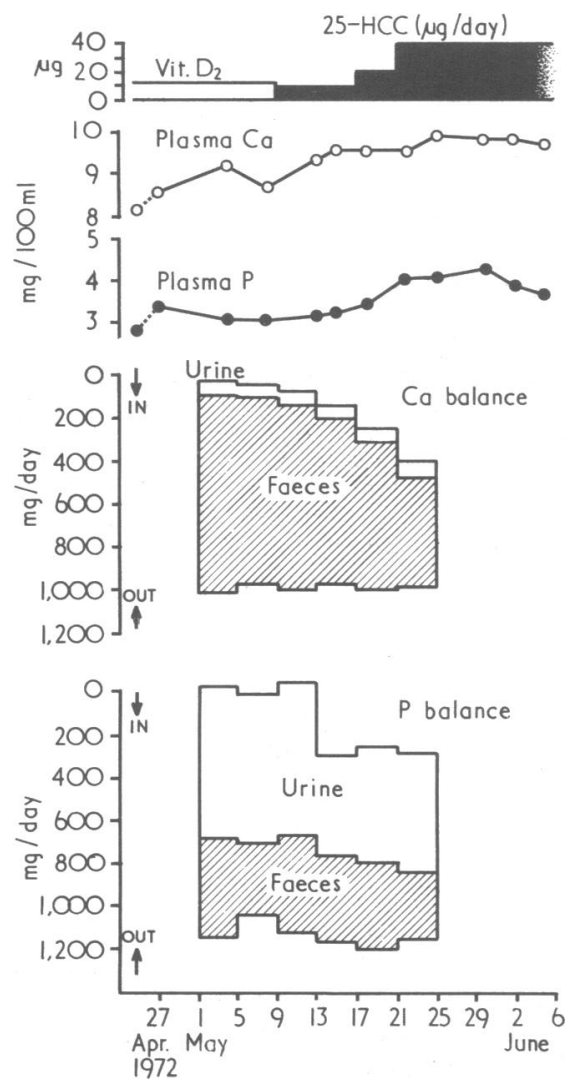

FIG. 3-Metabolic balance data in Case 2. Note steady stepwise improvement in calcium balance and plasma chemistry when 25-HCC, at first in a dose of $10 \mu \mathrm{g}$ daily, was substituted for long-term calciferol in a dose of $12.5 \mu \mathrm{g}$ daily.

\section{Discussion}

Plasma levels of 25-HCC measured by a specific radiocompetitive assay have not been previously reported for normal subjects in Great Britain. The present mean level of $15.8 \mathrm{ng} / \mathrm{ml}$ in adults is significantly lower than those of 27.3 and $20.5 \mathrm{ng} / \mathrm{ml}$ reported in the U.S.A. ( $P<0.05$ for the lower value) and determined in the same laboratory (Haddad and Chyu, 1971; Hahn, Hendin, Scharp, and Haddad, 1972). This difference presumably reflects both the higher dietary intake of vitamin $D$ and the higher exposure to effective sunshine in the U.S.A. (with its more southerly latitudes). The abnormally low levels of 25-HCC which have been found among epileptic patients in the present study must reflect alterations in vitamin $D$ metabolism, since diet and sunshine exposure in these patients were considered adequate. Hypocalcaemia occurs regularly among these patients (Richens and Rowe, 1970), and a close correlation between plasma calcium and 25-HCC has been observed (Hahn et al., 1972). It is therefore possible that 25-HCC may be an important determinant of plasma calcium levels and that the product-inhibited nature of 25-HCC synthesis by liver (DeLuca, 1971) may constitute a feedback mechanism for preventing vitamin $\mathrm{D}$ intoxication.

In a previous report it was found that anticonvulsant osteomalacia in two patients did not notably respond to calciferol administered parenterally in a mean daily dosage of $50 \mu \mathrm{g}$ (2,000 IU) for varying periods of time (Dent et al., 1970). Case 1 in the present study did not respond to calciferol $45 \mu \mathrm{g}$ daily by mouth, and in Case 2 the patient had well-marked osteomalacia despite a daily vitamin D supplement of 500 units which he had taken for over a year. We have treated a 9-year-old Indian boy suffering from florid anticonvulsant rickets with calciferol 5,000 units daily by mouth, and though radiological appearances had returned almost to normal after four months his plasma calcium was still abnormally low at $7.4 \mathrm{mg} / 100 \mathrm{ml}$ and reached normal values only after eight months of this treatment. Anticonvulsant rickets (and osteomalacia) therefore shows a moderate degree of resistance to treatment with vitamin D. This contrasts strikingly with the noticeable effectiveness of 25-HCC given in doses of 10-45 $\mu \mathrm{g}$ daily in the present study.

The antirachitic activity of 25-HCC under these conditions, though impossible to quantitate, is certainly several times greater than that of calciferol. This contrasts with its antirachitic potency in vitamin $\mathrm{D}$ deficient rats or chicks, which is merely in the region of $25 \%$ greater than cholecalciferol (DeLuca, 1970, 1971 , and personal communication). 25-HCC in doses of $10-45 \mu \mathrm{g}$ gaily in anticonvulsant osteomalacia appears roughly equivalent to the antirachitic activity of whole-body ultraviolet irradiation given to the limit of tolerance (that is irradiation which produces mild erythema). Two previously reported cases (Dent et al., 1970) were quickly healed by irradiation after small doses of calciferol had proved ineffective, one further case of anticonvulsant osteomalacia in a 43-year-old man healed equally quickly with no previous vitamin $\mathrm{D}$ given by mouth (unpublished data), and healing was well sustained by irradiation after 25-HCC in Case 1 of the present report.

Clinical studies using 25-HCC in other special diseasesnamely, hypoparathyroidism, the sex-linked variety of hypophosphataemic rickets, and chronic renal failure-have not indicated any clear superiority over the standard preparations of vitamin $D_{2}$ and $D_{3}$ in current use (Balsan, 1970; DeLuca and Avioli, 1970; Pak et al., 1970). If anticonvulsant osteomalacia can be regarded as a variant of the nutritional disease, with the normal requirement simply increased several times by physiological mechanisms, then present findings may indicate a pronounced species difference between man and rats in their relative response to calciferol and 25-HCC; other species differences in response to vitamin $\mathrm{D}$ analogues are well known (DeLuca, 1970). Alternatively 25-HCC, unlike calciferol, may in man, and in other species as well, in some way escape hydroxylation to inactive metabolites by drug-induced enzymes in its passage through the liver. Further trials of 25-HCC in nutritional rickets are in progress to clarify this problem.

T.C.B.S. acknowledges support from the Wellcome Trust. J.G.H. acknowledges N.I.H. research grant No. Am 14570-02 and Career Development Award No. K8-Am 70, 343-01. Bone biopsy studies were kindly performed by Dr. Paul Byers, and epileptic plasmas and patients were referred by Dr. Alan Richens. Supplies of 25-HCC were generously provided by Dr. H. F. DiLuca. Patients in the present study were admitted for metabolic balance studies under the care of Professor C. E. Dent.

\section{ADDENDUM}

A more recent report has suggested that 25-HCC may also be several times more potent than cholecalciferol on a weight basis in the treatment of familial hypophosphataemic rickets and of pseudo-vitamin D deficiency rickets. (Balsan and Garabedian, 1972).

\section{References}

Balsan, S. (1970). Calcified Tissue Research, 4, 45.

Balsan, S., and Garabedian, M. (1972). Fournal of Clinical Investigation, 5i, 749.

Deluca, H. F. (1969). American fournal of Nutrition, 22, 412.
Deluca, H. F. (1970). In International Encyclopaedia of Pharmacology and Therapeutics, ed. H. Rasmussen, section 51, vol. 1, p. 101. Oxford, Pergamon.

DeLuca, H. F. (1971). Recent Progress in Hormone Research, 27, 479.

DeLuca, H. F., and Avioli, L. V. (1970). Archives of Internal Medicine, 126, 896.

Dent, C. E., Richens, A., Rowe, D. J. F., and Stamp, T. C. B. (1970). British Medical fournal, 4, 69 .

Dick, M. (1969). Gut, 10, 408 .

Haddad, J. G., jun,, and Chyu, K. J. (1971). fournal of Clinical Endocrinology, 33, 992. 
Hahn, T. J., Hendin, B. A., Scharp, C. R., and Haddad, J. G., jun., (1972). New England fournal of Medicine. In press.

Holick, M. F., Schnoes, H. K., and DeLuca, H. F. (1971). Proceedings of the National Academy of Sciences, 68, 803 .

Kodicek, E., Lawson, D. E. M., and Wilson, P. W. (1970). Nature, 228, 763.

Kruse, R. (1968). Monatsschrift fürKinderheilkunde, 116, 378.
Lawson, D. E. M., Fraser, D. R., Kodicek, E., Morris, H. R., and Williams, D. H. (1971). Nature, 230, 228

Pak, C. Y. C., et al. (1970). Archives of Internal Medicine, 126, 239.

Reifenstein, E. C., jun., Albright, F., and Wells, S. L. (1945). Fournal of Clinical Endocrinology, 5, 367.

Richens, A., and Rowe, D. J. F. (1970). British Medical fournal, 4, 73.

\title{
Therapeutic Abortion by Intra-amniotic Injection of Prostaglandins
}

\author{
G. ROBERTS, \\ R. GOMERSALL, \\ M. ADAMS, \\ A. C. TURNBULL
}

British Medical fournal, 1972, 4, 12-14

\section{Summary}

Intra-amniotic injection of either prostaglandin $F_{2} \alpha$ or prostaglandin $E_{2}$ was used in an attempt to induce therapeutic abortion in mid-pregnancy in 27 patients. Termination of pregnancy was successful in 11 out of 13 cases when prostaglandin $E_{2}$ alone was used, but in only 6 out of 14 cases when prostaglandin $F_{2} \alpha$ was used. $A$ further eight patients aborted after additional intravenous oxytocin stimulation, but the combined procedures failed altogether in two patients who were initially given prostaglandin $\mathbf{F}_{2} \alpha$. The technique was simple, free from serious side effects, and reasonably effective when prostaglandin $E_{2}$ was used.

\section{Introduction}

The abortificient properties of prostaglandins have been publicized widely in both the medical and the lay press because they have been reported to be successful (Karim and Filshie, 1970, 1972) as well as safe. The existence of such an effective medical method for terminating pregnancy would argue against the continued use of surgical techniques, with their disadvantages of trauma, haemorrhage, and secondary infection. Other workers, however, have not been able entirely to confirm these reports of the efficacy of prostaglandins for termination in either early or mid-pregnancy (Wiqvist and Bygdeman, 1970; Roberts et al., 1971). Further trials are urgently needed to establish the best role for these potent drugs in clinical practice.

The intravenous administration of prostaglandins has been most extensively investigated to date. Although generally successful, its disadvantages are that it causes nausea, vomiting, and phlebitis and that in some cases the induction-abortion interval is prolonged. In an attempt to minimize or even eliminate systemic side effects other routes of administration have been tried, including transcervical extra-amniotic injection (Wiqvist and Bygdeman, 1970; Embrey and Hillier, 1971; Roberts et al., 1971). Recently the successful use of a single transabdominal intra-amniotic injection of prostaglandins for the induction of mid-pregnancy abortion was reported by Karim and Sharma (1971). The results of a similar trial in Cardiff are now presented, including some data obtained by recording myometrial contractility. Plasma oestrogens and progesterone were also measured in some of these patients and the results will be published in a separate report (Symonds et al., 1972).

\footnotetext{
Department of Obstetrics and Gynaecology, University Hospital of Wales, Cardiff Maternity Hospital, Cardif

G. ROBERTS, M.B., M.R.C.o.G., Senior Registrar

R. GOMERSALL, M.B., M.R.C.O.G., Registrar

M. ADAMS, M.B., B.CH., Senior House Officer

A. C. TURNBULL, M.D., F.R.C.o.G., Professor
}

\section{Patients and Methods}

The study was performed on 27 patients with pregnancies of between 14 and 22 weeks' gestation. Each patient was sedated with $10 \mathrm{mg}$ of morphine and $5 \mathrm{mg}$ of perphenazine by intramuscular injection given about one hour before the procedure. Transabdominal amniocentesis with an 11-gauge needle was performed under local anaesthesia ( $1 \%$ lignocaine). A polyethylene cannula was inserted through the needle into the amniotic cavity and the needle withdrawn over it. Uterine activity was monitored when possible by connecting the cannula to a Devices pressure transducer and recorder. Basal uterine activity was recorded for 30 minutes before administration of the prostaglandins. Prostaglandin $\mathrm{F}_{2} \alpha$ was given as a single intra-amniotic injection of $25 \mathrm{mg}(5 \mathrm{mg} / \mathrm{ml})$ in the first 14 cases, except for one patient (Case 10) who was given three such doses at intervals of 24 hours for three successive days. Prostaglandin $E_{2}$ was used in the next 13 cases, a different regimen being followed (by request of the manufacturers). This consisted of an initial injection of $1 \mathrm{mg}(1 \mathrm{mg} / \mathrm{ml})$ followed by two further 1-mg doses at 10-minute intervals. Because uterine activity diminished in some patients (Cases 18, 21, 23, 25 , and 26) further 3-mg intra-amniotic injections were given (see Table II). In all patients pulse rate, blood pressure, and body temperature were recorded every four hours and analgesic drugs were prescribed when required. Intravenous oxytocin infusions were used when pregnancy could not be terminated with prostaglandins alone. Hysterotomy was performed only when all the "medical" methods had failed.

A complete record of amniotic fluid pressure changes was obtained from only two patients (Cases 1 and 5). Transient blockage of the cannula was common so that many tracings were intermittent, and in other cases monitoring was discontinued on ethical grounds because induction of abortion was proving so prolonged.

\section{Results}

A single intra-amniotic injection of $25 \mathrm{mg}$ of prostaglandin $\mathrm{F}_{2} \alpha$ successfully terminated pregnancy in only six out of 14 cases, the average induction-delivery interval being 19 hours 31 minutes (Table I). In a further six patients cervical dilation had reached $2 \mathrm{~cm}$ after intervals varying from 24 to 48 hours, and intravenous oxytocin infusions were then required to stimulate effective uterine activity. In this group the average induction-abortion interval was 59 hours, being particularly prolonged in primigravidae. Two patients (Cases 6 and 14) failed to abort at all. The cervix remained tightly closed despite further attempts to augment uterine activity by injecting hypertonic saline into the amniotic sac and giving additional intravenous infusions of oxytocin. Hysterotomy had to be performed in both these cases. Abortion was incomplete in seven of the 12 patients who were delivered vaginally.

In patients given prostaglandin $\mathrm{E}_{2}$ the success rate was much 